\title{
"The influence of a paperless office environment on the sustainability of the Master of the High Court in Cape Town"
}

$\begin{array}{ll} & \text { Luthando Tyhulu } \\ & \text { Bongani Sibande } \\ & \text { Nkosinathi Zilwa } \\ & \text { Siphiwo Langa } \\ \text { SUTHORS } & \text { Shairn Hollis-Turner } \\ & \text { Juan-Pierré Bruwer } \\ & \text { Luthando Tyhulu, Bongani Sibande, Nkosinathi Zilwa, Siphiwo Langa, Shairn } \\ \text { ARTICLE INFO } & \text { Hollis-Turner and Juan-Pierré Bruwer (2016). The influence of a paperless office } \\ & \text { environment on the sustainability of the Master of the High Court in Cape Town. } \\ & \text { Environmental Economics, 7(3), 33-44. doi:10.21511/ee.07(3).2016.04 }\end{array}$

DOI http://dx.doi.org/10.21511/ee.07(3).2016.04

RELEASED ON

Friday, 21 October 2016

JOURNAL

"Environmental Economics"

FOUNDER

LLC "Consulting Publishing Company "Business Perspectives"

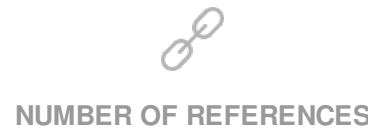

0
NUMBER OF FIGURES

0
NUMBER OF TABLES

0

(C) The author(s) 2022. This publication is an open access article. 
Luthando Tyhulu (South Africa), Bongani Sibande (South Africa), Nkosinathi Zilwa (South Africa), Siphiwo Langa (South Africa), Shairn Hollis-Turner*** (South Africa), Juan-Pierré Bruwer (South Africa)

\title{
The influence of a paperless office environment on the sustainability of the Master of the High Court in Cape Town
}

\begin{abstract}
Around the globe, more emphasis is being placed on environmental sustainability and, as such, many organizations have started to embrace the idea of a paperless working environment, although it is still largely regarded as an idealistic dream. For this research study, the influence of a paperless working environment on the Master of the High Court (Master's Office), in Cape Town, was investigated through the introduction of its Paperless Estate Administration System (PEAS) and its Paperless Estate Administration System for Trusts (PEAST). The main objective of this research study is to determine the influence of the PEAS and the PEAST on the holistic sustainability of the Master's Office. A mixed methods approach was followed whereby both quantitative data and qualitative data were collected through means of disseminating questionnaires to employees based at the Master's Office in Cape Town. Based on the findings made, the PEAS and the PEAST had a positive influence on the sustainability of the Master's Office in Cape Town, as the time spent on and the expenditure incurred on administrative tasks decreased significantly. Notwithstanding the latter, it was found that the PEAS and the PEAST can still be further enhanced to optimize the sustainability of the Master's Office in Cape Town.
\end{abstract}

Keywords: paperless, work environment, high court, administration, office and management technology, Paperless Estate Administration System (PEAS), Paperless Estate Administration System for Trusts (PEAST).

JEL Classification: M10.

\section{Introduction}

Despite the popularity of paper in working environments, advancements made in technology, over the years, have encouraged many organizations, in recent times, to shift their focus towards a "paperless working environment" (Orantes-Jiménez et al., 2015). Albeit the latter, previous research studies (Gupta, 2015; Hill, 2015) make mention that a paperless working environment is still regarded as an idealistic dream. In order to understand where the need for a paperless working environment stems from, it is important to place emphasis on relevant historic developments.

During the Industrial Revolution (between the early 1760 s and the early 1840s), the use of paper started to become popular. The popularity to make use of paper was spurred on by the ever-growing need for printed money (printed bank notes) and the publication of information in the form of, inter alia,

\footnotetext{
(C) Luthando Tyhulu, Bongani Sibande, Nkosinathi Zilwa, Siphiwo Langa, Shairn Hollis-Turner, Juan-Pierré Bruwer, 2016.

Luthando Tyhulu, Faculty of Business and Management Sciences, Cape Peninsula University of Technology, South Africa.

Bongani Sibande, Faculty of Business and Management Sciences, Cape Peninsula University of Technology, South Africa.

Nkosinathi Zilwa, Faculty of Business and Management Sciences, Cape Peninsula University of Technology, South Africa.

Siphiwo Langa, Faculty of Business and Management Sciences, Cape Peninsula University of Technology, South Africa.

Shairn Hollis-Turner, Dr., Faculty of Business and Management Sciences, Cape Peninsula University of Technology, South Africa.

Juan-Pierré Bruwer, Faculty of Business and Management Sciences, Cape Peninsula University of Technology, South Africa.
}

guides, reports, newspapers, books, and magazines (Williams et al., 1987; Mokyr, 1997; Gladwell, 2002). As time elapsed, however, especially during the Second Industrial Revolution (between the early 1870s and the mid 1910s), continuous technological breakthroughs made it possible to both print money and publish information at faster paces (Greenwood, 1999); particularly attributable to the discovery of mass production (Macrae, 1951; Cowan, 1976).

Although many more innovative technological discoveries were made prior to the late $1950 \mathrm{~s}$, technology became even more advanced during the Digital Revolution (between the late 1950s and the late 1970s), as the printing of money and the publication of information became almost instant (Germain, 2007). Moreover, this same technology hinted towards the possibility of printing and publishing in a virtual dispensation in the nearby future (Van Meel, 2011). As a result, predictions were made that the use of paper (particularly in working environments) would decrease closer to the start of the 1980s, realizing the vision of a paperless working environment (Bloomberg, 1975).

Ironically, despite the aforesaid prediction, technological enhancements made the use of paper to grow even more popular (and convenient) as from the early 1980s, particularly in working environments (Sellen \& Harper, 2002; McAllister, 2005; Sanders, 2009). Even with the discovery of advanced computer-related technology during the Information Age (as from the early 1980s), this 
technology contributed to a paperless working environment to a marginal extent only (Mphidi \& Snyman, 2004), particularly since: 1) computerrelated technology (as it is known today) made "instant printing" and "instant publication" both a virtual reality and physical reality (Liu, 2008; Meyer, 2009) and 2) the cost of paper has not increased drastically over the years (Yang et al., 2007).

Notwithstanding the above, the cost of ink increased drastically over the years; from US\$ 13.00 per ounce in the early 1980s to approximately US\$75.00 per ounce in more recent times (Consumer Reports, 2013). To place the (potential) cost of ink to organizations in perspective, prior research shows that the global consumption of paper has been in excess of 140 million tons since the early 1980s (Sellen \& Harper, 2002). Therefore, it is of no surprise that many organizations across the globe have started to place more focus on becoming "green friendly" (Gokhale \& Sharma, 2014) in order to attain relevant organizational objectives without causing harm to the natural environment (Wilkinson et al., 2001; Bradwell, 2005). In order to assist organizations to become "green friendly", an array of paperless working environment initiatives have been proposed over the years which promotes, inter alia: 1) easy access to documentation, 2) the saving of storage space in offices, and 3) disaster recovery and backup initiatives (Brooks, 2014).

Recently, the South African Department of Justice (2013) took the first step in relation to implementing a paperless working environment initiative(s), particularly through the introduction of its Paperless Estate Administration System (PEAS) and its Paperless Estate Administration System for Trusts (PEAST). The initial phases of development of the PEAS and the PEAST were finalized between 2011 and 2012; first tested at the Master of the High Court (Master's Office) in Pretoria. After thorough tests were conducted, these systems were implemented at Masters' Offices throughout South Africa. Within a matter of two years after the national implementation of the PEAS and the PEAST, these systems were deemed by various stakeholders as "electronic blessings", as it allows for the easy storage of evidence which, in turn, can be easily recalled and searched for on these systems (Law Society of South Africa, 2015).

Although the PEAS and the PEAST have been reported to have a positive influence on service delivery and time management at the Masters' Offices throughout South Africa (Department of Justice, 2013), a recent report shows that the relevant objectives set around these systems, by individual staff members, are not always achieved owing to
1) "teething problems" with these systems and 2) a "lack of training" with regard to these systems (Department of Justice and Constitutional Development, 2016a).

Stemming from the above, this research study was conducted to determine the influence of the PEAS and the PEAST on the overall sustainability ${ }^{1}$ of the Master's Office in Cape Town. In particular, the primary research objective pertaining to this research study which is as follows:

To ascertain the influence which the PEAS and the PEAST have on the attainment of objectives in the Master's Office in Cape Town, for the foreseeable future.

For the sake of clarity, the remainder of this research paper is demarcated under the following sections: 1) literature review, 2) research design and methodology, 3) findings and discussions, recommendations, and conclusion.

\section{Literature review}

1.1. The historic development of a paperless office environment in South Africa. In the context of this research study, the advancement from paper based record keeping to electronic record keeping is central to the historical development of the paperless environment in South Africa.

Public records are valuable resources (State of the Archives, 2014) which bring and offer recorded evidence and perspective on virtually every aspect of South African life, past and present. According to Harris (1997), Khoisan rock paintings and patterns in dwellings, which extend back to $2500 \mathrm{BC}$ (Beaumont \& Vogel, 1989), can be regarded as some of the first public South African records. Paper-based records started to become more prevalent in South Africa especially during the colonization of the Cape (Harris, 2000) which is supported by paper-based records which stem from the Dutch East India Company (DEIC) between 1652 to 1795 (Gerber, 1987; Verster, 2007). During the DEIC's rule of the Cape (TANAP, 2015), each government office controlled its own records which continued during the brief Batavian Republic rule of the Cape (1803 - 1806).

During the second British rule of the Cape (1806 1901), the custody of records was the function of the Colonial Secretary. In 1876, the Cape government appointed an ad hoc commission tasked with collecting, examining, indexing and making accessible the records of the Colony. This can be viewed as the foundation of South Africa's institutionalized

\footnotetext{
${ }^{1}$ The attainment of relevant objectives in the foreseeable future through means of attaining relevant social responsibilities, economic responsibilities and environmental responsibilities (Bechtold et al., 2013).
} 
archival system as an instrument intended primarily to preserve records of government (State of the Archives, 2014).

Between 1901 and 1910, former colonies of South Africa (the Cape, Transvaal, Orange River and Natal) were incorporated to form the "Union of South Africa in 1910", resulting in the formation of a single archives service under the Department of Interior under the control of a Chief Archivist (Harris, 2000). In 1922, the Union of South Africa passed the Public Archives Act creating the State Archives Service of South Africa (SAS) under the responsibility of the Department of the Interior (Harris, 2000). The extension of the powers of the Chief Archivist in relation to care, control and disposition of public records emerged in the Archives Act No. 22 of 1953 (State of the Archives, 2014), as a means of strengthening apartheid bureaucracy by the National Party. In 1957, a Liaison Section was created at the office of the Chief Archivist to manage records archiving (Ngulube, 2006). In 1960 (Ngoepe \& Keakopa, 2011), the name of the Section was changed to Records Management Section, a name still prevalent today.

Towards the end of 1969 , considerable progress had been made in the achievement of efficient records management (Harris, 2002). However, these were soon to face challenges with the increased popularity of using computers to create electronic records at the start of the 1970s (Ngoepe, 2008b). Traditional paper records (e.g., policy documents, memos, letters and reports), legislation and historic documents could be stored and accessed in an orderly manner (Ngulube, 2003). These electronic measures were faced by some controlrelated challenges which included concerns over; then, modern software being readable by future hardware owing to rapid changing computer systems (Ngoaketsi, 2003), 'media deterioration', as well as the National Archives and Records Service of South Africa's (NARSA) limited expertise in the area of electronic records keeping (Directorate State Archives and Heraldic Services, 1999), and the custody of certain types of electronic records (Ngoepe, 2008b). As a result, in 1974, the State Archives Services of South Africa advised all state offices and local authorities that electronic records, like any other records, were also subject to the National Archives Act.

Between 1974 and 1985, the use of electronic recordkeeping and electronic archiving became even more popular with the introduction of word processing systems (Kirkwood \& Venter, 1999). As such, in 1993, government motivated the use of full electronic recordkeeping and electronic archiving (Ngulube, 2002). The National Archives and Records Service Act No. 43 of 1996 gave responsibility for the management of electronic records to NARSA resulting in the decision to permanently preserve certain types of electronic records in the office of origin. It was soon realized that this was not feasible unless additional staff were hired and trained which would have prevented government bodies from performing their core duties, hence, the Act was retracted (Abbot, 2001).

In 2000, the NARSA published guidelines for managing all formats of records in an integrated manner (Mukwevho \& Jacobs, 2012). However, these guidelines were not simple and NARSA did not have the appropriate infrastructure to take electronic records into archival custody (Ngulube, 2006). By 2007, the archiving of electronic records remained with NARSA having a small and basic electronic archive, while none of the provincial archives services had capacity in this area (Mukwevho \& Jacobs, 2012), as many government departments had not customized the unclear guidelines (Ngoepe, 2008b).

1.2. The impact of a paperless office environment in South Africa since 2010. Taking into account that South Africa has the ability to implement electronic record keeping and electronic articling, since 2010, it has not yet sufficiently developed a way in which the effectiveness of electronic interventions can be evaluated (Muchaonyerwa \& Khayundi, 2014). Ngoepe and Van der Walt (2009) share the view that even with the NARSA adopting electronic records management policies and strategies that are benchmarked against international standards, the NARSA still lacks electronic records preservation infrastructure and, furthermore, its staff lack technical skills to manage a trusted digital repository.

Research conducted by Muchaonyerwa and Khayundi (2014) reveal that government's commitment to e-government as a strategy for improved service delivery has resulted in increased generation of electronic records. As a result, NARSA has committed to ensuring that electronic records remain accessible and understandable (Moloi, 2001). In addition, to promote generation and preservation of quality records the NARSA subscribes to principles that apply to the management of electronic records which include: 1) classification systems, 2) the 
appraisal and disposal of records, 3) long-term preservation initiatives, 4) metadata maintenance, 5) version control, 6) authenticity checking, and 7) back-up and disaster recovery plans (National Archives and Records Service of South Africa, 2006).

Though these measures are in place, the recent transition from paper-based to electronic records in South Africa has not been flawless, as "barrier to entry" has been cited as one of the challenges to the transition to electronic records, triggered by most people previously being accustomed to paper records (Weeks, 2014). Kwatsha (2010) notes that the transition to electronic records prompted by existing problems with paper-based records resulted in the attainment of only some of the benefits. One of the attributions of this was a lack of enthusiasm shown by the users owing to inadequate training received. Johnston and Bowen (2005) emphasize if the human elements of a system being implemented are important, then, special care must be given to training and it should be used as part of a change management process. Prominent from the above is that in order to address previous shortcomings, government needs to implement and exercise certain measures in the public sector.

Notwithstanding the above, elsewhere in the public sector, the South African Statistical Quality Assessment Framework (SASQAF) has been developed to establish standards to evaluate the quality of records in all forms (including electronic), and to generate and present reliable information of satisfactory quality for decision making (Statistics South Africa, 2010; The Presidency, 2009). It is, however, clear that even with SASQAF in place, the public sector is unable to fully adhere to the guidelines provided, resulting in the tempering of the quality of public electronic records (Mukwevho \& Jacobs, 2012). Yuba (2013) concludes that issues such as staff shortage, high staff turnover, low salaries, and the undervalue of NARSA by governmental bodies are sufficient factors to lead to the conclusion that NARSA, as the body tasked with proper management and care of records of all government bodies, has neglected records management.

This failure to resource the NARSA has led to the failure to develop the necessary infrastructure for the preservation of electronic records, thus, culminating in the government's accountability being compromized, and the heritage of governance in the democratic South Africa being jeopardized (Ngoepe \& Van der Walt, 2009). Failure by governmental bodies to integrate risk management and records keeping as necessary has led to the failure to identify business risks, as well as opportunities (Ngoepe, 2014). Owing to their underwhelming use, public records have failed to regularly enhance government operations. Evident above are government failures to utilize electronic records to their advantage.

\subsection{Overview of the Master's Office in Cape} Town. The Master's Office is a South African government department that falls under the Department of Justice and Constitutional Development (DoJCD) - each of the nine provinces in the country has its own division (Department of Justice and Constitutional Development, 2016b).

The history of the Master's Office can be traced back to 1674 and its predecessors can be found in the archives of some European countries long before Jan van Riebeeck arrived in the Cape in 1652 (Calitz \& Boraine, 2005). After 1652, the administration of insolvent estates (a function of the Master's Office), was in the hands of a "Sequester"; an official who was a member of the council of justice and tasked with the administration of between 300-400 estates (De Villiers, 1923). In more recent times, however, the Master's Office has the powers granted by the following legislation: 1) Administration of Estates Act No. 66 of 1965, the Insolvency Act No. 24 of 1936, the Companies Act No. 61 of 1973, the Close Corporations Act No. 69 of 1984, and the Trust Property Control Act No. 57 of 1988 being some of the most important. Apart from regulating insolvencies, the Master's Office has the following functions (Calitz \& Boraine, 2005):

- Controlling the administration of deceased estates, including the acceptance and custodianship of wills.

- Controlling the registration and administration of both testamentary trusts and trusts inter vivos.

- Management of guardians' funds which are entrusted with the funds of minors, mentally challenged persons, unknown and/or absent heirs and creditors for administration on their behalf.

- Supervising estates and acting as custodian over minors and mentally challenged persons.

- Acting as an office of record.

In terms of the Prevention of Organized Crime Act, certain powers and duties are also bestowed upon the Master.

Most of the functions of the Masters' Office are carried out by the two departments, namely the Deceased Estate Department and the Trust Department. For this research study, employees based in the Deceased Estate Department and the Trust Department, in Cape Town, were approached for data. 
1.3.1. Deceased Estate Department. Department of Justice and Constitutional Development (2016c) discloses that the purpose of reporting a Deceased Estate is to ensure the appointment of an executor/Master's representative to wind up the financial affairs of the deceased, and further the protection of the financial interest of the heirs. An executor/Master's representative administers and distributes the estate of a deceased in terms of the deceased will or if no valid will, in terms of Intestate Succession Act No. 81 of 1987.

1.3.2. Trust Department. The Master appoints trustees in the Trust Department (Department of Justice and Constitutional Development, 2016d) who administer all trusts which are governed by the provisions of the Trust Property Control Act No. 57 of 1988. An inter vivos trust (created between living persons) and a testamentary trust (derives from a valid will of a deceased) are the two types of trusts.

1.3.3 Staff at the Master's Office. South Africa (2013) reveals that the year 2013 was significant for the Master's Office in Cape Town as it; relocated into new premises in an effort to make it accessible to the public, and implemented the PEAS and the PEAST systems in order to improve service delivery. Subsequently, staff at the Master's Office who are in regular contact with attorneys, chartered accountants, insolvency practitioners, inter alia, are called upon to work with those not previously exposed to the functions and duties of the Masters' Offices Department of Justice and Constitutional Development (2016a).

The Master's Office in Cape Town employs more than 150 employees with varying job titles, inter alia, Assistant Master, Senior Registry Clerk, Estate Controller, Administration Clerk, Deputy Master, Chief Registry Clerk, Accounting Clerk, Assistant Director and Estate controller. Some of these employees are based in the Deceased Estate Appointment, Deceased Estate, Examination of VAT Distribution Account, Guardian Fund, Trust, Curatorship, and Insolvency sections of the Master Office. Several of the positions occupied by these employees generally have Grade 12 as one of the minimum requirements, while only persons with prescribed legal qualifications can be appointed as Master, Deputy Master or Assistant Master (Calitz \& Boraine, 2005). Currently, 99\% of Estate Controllers, the Deputy Master and Master have legal qualifications.

The majority of employees that interact on a daily basis with the PEAS and the PEAST systems are from the Deceased Estate, and Trust sections of the Master's Office. In the Deceased Estate Department, employees are divided into groups according to the nature of their duties. Each group comprises of 8 employees with similar job titles: Assistant Master, Registry Clerk, Admin Clerk, and Estate Controller (Department of Justice and Constitutional Department, 2016a).

\section{Research design and methodology}

The research design of this research study pertained to that of empirical research (Leedy \& Ormrod, 2010). In particular, survey research was used (Collis \& Hussey, 2009) whereby a questionnaire-tool was developed in order to obtain both quantitative and qualitative primary data from relevant respondents. The questionnaire-tool comprised of the following types of questions: 1) six multiple choice questions (quantitative), 2) nine Likert-scale questions (quantitative), 3) four yes/no questions (quantitative), and 4) five open-ended questions (qualitative). Hence, taking into account the aforementioned, the research methodology that was deployed throughout this research study was strongly relative to mixed-methods research (Remenyi, Williams, Money \& Swartz, 2009).

This research study placed emphasis on the PEAS and the PEAST in the Master's Office in Cape Town. It was decided to make use of non-probability sampling methods (Collis \& Hussey, 2009) - purposive sampling - in order to select a representative sample size from a specific targeted population. The chosen targeted population was those employees of the Master's Office in Cape Town that made direct use of the PEAS and the PEAST who, in turn, had to adhere to the following delineation criteria:

- Employees had to be based in either the Deceased Estate Department or the Trusts Departments at the Master's Office in Cape Town.

- Employees had to have at least 6 months' working experience in the Master's Office in Cape Town.

- Employees had to have interacted with either the PEAS or the PEAST before.

A total of 32 positive responses were received and all respondents: 1) were safeguarded from physical harm, 2) were guaranteed of the confidentiality of information provided, 3) were guaranteed of anonymity, and 4) participated in this research study on a voluntary basis.

\section{Findings and discussions}

All relevant findings and discussions are covered under the following headings below: 1) demographical information of respondents, 2) evaluation of the PEAS and the PEAST, and 3) respondents' views of the PEAS and the PEAST.

\subsection{Demographical information of respondents.} Stemming from the findings made, $100 \%$ of respondents adhered to the developed delineation criteria of this research study. In particular, it was 
found that: 1) $78.13 \%$ of respondents were based in the Deceased Estate Department, while $21.88 \%$ of respondents were based in the Trust Department, 2) $78.13 \%$ of respondents made use of PEAS, while $21.88 \%$ of respondents made use of PEAST, and 3) $100 \%$ of respondents were employed at the Master's Office for at least 6 months.

When respondents were asked about their age(s), the following dispensation emerged in Table 1:

Table 1. Frequency distribution table of respondents' age(s)

\begin{tabular}{|l|c|c|c|c|c|}
\hline \multicolumn{1}{|c|}{ Value label } & Value & Frequency & Percent & $\begin{array}{c}\text { Valid } \\
\text { percent }\end{array}$ & $\begin{array}{c}\text { Cum } \\
\text { percent }\end{array}$ \\
\hline $\begin{array}{l}\text { Between } 18 \text { years } \\
\text { and 25 years }\end{array}$ & 1 & 1 & 3.13 & 3.13 & 3.13 \\
\hline $\begin{array}{l}\text { Between 26 years } \\
\text { and 35 years }\end{array}$ & 2 & 12 & 37.50 & 37.50 & 40.63 \\
\hline $\begin{array}{l}\text { Between } 36 \text { years } \\
\text { and 45 years }\end{array}$ & 3 & 10 & 31.25 & 31.25 & 71.88 \\
\hline $\begin{array}{l}\text { Older than 45 } \\
\text { years }\end{array}$ & 4 & 9 & 28.13 & 28.13 & 100.00 \\
\hline Total & & 32 & 100.0 & 100.0 & \\
\hline
\end{tabular}

Stemming from the results in the Table above, it appears that the age of the average respondent (68.75\% of the time) ranged between the ages of 26 years and 45 years. The inference can, therefore, be made that employees were largely classified as members of Generation $X$ - a generation which is believed to treasure: 1) a sense of belonging, 2) a sense of teamwork, 3) the ability to learn new things, 4) independence, 5) (job) security, 6) (time) flexibility, and recognition (Jurkiewicz, 2000). For this very reason, it is highly probable that respondents may have had a negative attitude towards the PEAS and/or the PEAST, since these systems were implemented in order to "automate" and "speed-up" operations.

In addition to the aforesaid, and in relation to gender, a total of $90.63 \%$ of respondents were found to be female, while the remaining $9.38 \%$ were male. When respondents were asked about their ethnicity, the following dispensation emerged in Table 2:

Table 2. Frequency distribution table of respondents' ethnicity

\begin{tabular}{|l|c|c|c|c|c|}
\hline Value label & Value & Frequency & Percent & $\begin{array}{c}\text { Valid } \\
\text { percent }\end{array}$ & $\begin{array}{c}\text { Cum } \\
\text { percent }\end{array}$ \\
\hline African & 1 & 10 & 31.25 & 31.25 & 31.25 \\
\hline Coloured & 2 & 11 & 34.38 & 34.38 & 65.63 \\
\hline Indian & 3 & 1 & 3.13 & 3.13 & 68.75 \\
\hline White & 4 & 10 & 31.25 & 31.25 & 100.00 \\
\hline Total & 32 & 100.0 & 100.0 & \\
\hline
\end{tabular}

From the Table above, it appears that the diversity of employees in the Master's Office in Cape Town was quite suitable, especially when taking into consideration applicable employment legislation (e.g., Employment Equity Act No 55 of 1998, Employment Equity Amendment Act No 47 of 2013, etc.).

Lastly, when respondents were asked about their working experience, based on number of years, $6.25 \%$ of respondents indicated "between 6 months and one year", $18.75 \%$ indicated "between one year and two years", $6.25 \%$ indicated "between three years and four years", and $68.75 \%$ indicated "more than four years".

3.2. Evaluation of the PEAS and the PEAST. In order to understand respondents' perceptions pertaining to the PEAS and the PEAST, they were asked to evaluate a total of seven statements through means of a four point Likert scale ${ }^{2}(1=$ strongly agree, $2=$ agree, $3=$ disagree, and $4=$ strongly disagree). A summary of the results is presented in Table 3 below:

Table 3. The evaluation of respondents of the PEAS and the PEAST

\begin{tabular}{|l|l|l|l|l|l|l|}
\hline \multicolumn{1}{|c|}{ Statement } & $\begin{array}{c}\text { Strongly } \\
\text { agree }\end{array}$ & Agree & Disagree & $\begin{array}{c}\text { Strongly } \\
\text { disagree }\end{array}$ & Mean & $\begin{array}{c}\text { Std } \\
\text { dev. }\end{array}$ \\
\hline $\begin{array}{l}\text { The system has } \\
\text { improved the } \\
\text { retrieval of } \\
\text { information }\end{array}$ & $6.25 \%$ & $68.75 \%$ & $15.63 \%$ & $9.38 \%$ & 2.28 & 0.73 \\
\hline $\begin{array}{l}\text { The system } \\
\text { allows me to } \\
\text { respond quickly } \\
\text { to customer } \\
\text { enquiries }\end{array}$ & $12.50 \%$ & $43.75 \%$ & $40.63 \%$ & $3.13 \%$ & 2.34 & 0.75 \\
\hline $\begin{array}{l}\text { The system } \\
\text { allows me to } \\
\text { make accurate } \\
\text { decisions }\end{array}$ & $3.13 \%$ & $43.75 \%$ & $50.00 \%$ & $3.13 \%$ & 2.53 & 0.62 \\
\hline $\begin{array}{l}\text { The system } \\
\text { allows me to } \\
\text { search for } \\
\text { information, } \\
\text { easier }\end{array}$ & $9.38 \%$ & $75.00 \%$ & $9.38 \%$ & $6.25 \%$ & 2.13 & 0.66 \\
\hline
\end{tabular}

Based on the results in Table 3, it appears that respondents were largely in agreement that the PEAS and the PEAST improved the retrieval of information (mean score of 2.28), as well as making the search for information easier (mean score of 2.13). In addition, respondents were only partially in agreement that the PEAS and the PEAST allowed them to respond quicker to customer enquiries (mean score of 2.34), while respondents were more in disagreement that the PEAS and the PEAST allowed them to make accurate decisions. Stemming from the above, the inference can be made that the PEAS and the PEAST did add value to respondents. Hence, using the aforesaid as basis, the inference can be made that the PEAST and the

${ }^{2}$ Although a five-point Likert scale could have been used, respondents were asked to rate statements with the main intent to determine whether the PEAS and the PEAST were better alternatives to the old paper working environment. 
PEAS had a positive influence on the overall working environment of respondents, especially since it saved respondents' time in relation to basic administration, particularly the search and retrieval of information. In relation to the earlier inference made that respondents may have had a negative attitude towards the PEAS and/or the PEAS (see section 3.1), a cross tabulation was performed between the ages of respondents and their evaluation of statements pertaining to the PEAS and the PEAST. The latter is shown in Table 4.

Table 4. Comparing the age of respondents and their evaluations of the PEAS and the PEAST

\begin{tabular}{|c|c|c|c|c|c|}
\hline Evaluation & $\begin{array}{l}\text { Between } 18 \text { years and } \\
25 \text { years }\end{array}$ & $\begin{array}{l}\text { Between } 26 \text { years and } \\
35 \text { years }\end{array}$ & $\begin{array}{l}\text { Between } 36 \text { years and } \\
45 \text { years }\end{array}$ & $\begin{array}{c}\text { Older than } 45 \\
\text { years }\end{array}$ & TOTAL \\
\hline $\begin{array}{l}\text { The system has improved the retrieval of } \\
\text { information (strongly agree) }\end{array}$ & - & $6.25 \%$ & - & - & $6.25 \%$ \\
\hline $\begin{array}{l}\text { The system has improved the retrieval of } \\
\text { information (agree) }\end{array}$ & $21.88 \%$ & $18.75 \%$ & $3.13 \%$ & $25.00 \%$ & $68.75 \%$ \\
\hline $\begin{array}{l}\text { The system has improved the retrieval of } \\
\text { information (disagree) }\end{array}$ & $3.13 \%$ & $6.25 \%$ & - & $6.25 \%$ & $15.63 \%$ \\
\hline $\begin{array}{l}\text { The system has improved the retrieval of } \\
\text { information (strongly disagree) }\end{array}$ & $6.25 \%$ & $3.13 \%$ & - & - & $9.38 \%$ \\
\hline \multicolumn{5}{|l|}{ TOTAL } & $100 \%$ \\
\hline $\begin{array}{l}\text { The system allows me to respond quickly to } \\
\text { customer enquiries (strongly agree) }\end{array}$ & $6.25 \%$ & $6.25 \%$ & - & - & $12.50 \%$ \\
\hline $\begin{array}{l}\text { The system allows me to respond quickly to } \\
\text { customer enquiries (agree) }\end{array}$ & $21.88 \%$ & $12.50 \%$ & - & $9.38 \%$ & $43.75 \%$ \\
\hline $\begin{array}{l}\text { The system allows me to respond quickly to } \\
\text { customer enquiries (disagree) }\end{array}$ & $3.13 \%$ & $15.63 \%$ & - & $21.88 \%$ & $40.63 \%$ \\
\hline $\begin{array}{l}\text { The system allows me to respond quickly to } \\
\text { customer enquiries (strongly disagree) }\end{array}$ & - & - & $3.13 \%$ & & $3.13 \%$ \\
\hline \multicolumn{5}{|l|}{ TOTAL } & $100 \%$ \\
\hline $\begin{array}{l}\text { The system allows me to make accurate decisions } \\
\text { (strongly agree) }\end{array}$ & - & 3.13 & - & - & $3.13 \%$ \\
\hline $\begin{array}{l}\text { The system allows me to make accurate decisions } \\
\text { (agree) }\end{array}$ & $15.63 \%$ & $12.50 \%$ & - & $15.63 \%$ & $43.75 \%$ \\
\hline $\begin{array}{l}\text { The system allows me to make accurate decisions } \\
\text { (disagree) }\end{array}$ & $12.50 \%$ & $18.75 \%$ & $3.13 \%$ & $15.63 \%$ & $50.00 \%$ \\
\hline $\begin{array}{l}\text { The system allows me to make accurate decisions } \\
\text { (strongly disagree) }\end{array}$ & $3.13 \%$ & - & - & - & $3.13 \%$ \\
\hline \multicolumn{5}{|l|}{ TOTAL } & $100 \%$ \\
\hline $\begin{array}{l}\text { The system allows me to search for information, } \\
\text { easier (strongly agree) }\end{array}$ & $3.13 \%$ & $6.25 \%$ & - & - & $9.38 \%$ \\
\hline $\begin{array}{l}\text { The system allows me to search for information, } \\
\text { easier (agree) }\end{array}$ & $21.88 \%$ & $21.88 \%$ & $3.13 \%$ & $28.13 \%$ & $75.00 \%$ \\
\hline $\begin{array}{l}\text { The system allows me to search for information, } \\
\text { easier (disagree) }\end{array}$ & $3.13 \%$ & $3.13 \%$ & - & $3.13 \%$ & $9.38 \%$ \\
\hline $\begin{array}{l}\text { The system allows me to search for information, } \\
\text { easier (strongly disagree) }\end{array}$ & $3.13 \%$ & $3.13 \%$ & - & & $6.25 \%$ \\
\hline \multicolumn{5}{|l|}{ TOTAL } & $100 \%$ \\
\hline
\end{tabular}

From the results in Table 4, after offsetting the positive and negative evaluations of the PEAS and/or the PEAST by respondents between the ages of 26 years and 45 years, it appears that they were in disagreement with the statements made that the PEAS and/or the PEAST allowed them to make more accurate decisions $(21.88 \%$ disagreed, while $15.63 \%$ agreed), and allowed them to respond to customer enquiries quicker $(18.76 \%$ disagreed, while $18.75 \%$ agreed). In relation to the two remaining statements, respondents between the ages of 26 years and 45 years mostly agreed (at least $74.99 \%$ of the time).
Hence, although most respondents $(68.75 \%)$ were part of Generation X, the inference can be made that they had mostly a positive attitude towards the PEAS and the PEAST based on their evaluations of these systems. When emphasis is placed on the evaluations of all remaining respondents, the holistic conclusion can be made that the PEAS and the PEAST added value to respondents in relation to their administrative tasks, in most cases.

3.3. Respondents' views on the PEAS and the PEAST. Taking into account the above, it was important to understand how respondents viewed the PEAS and the PEAST from a personal point of 
view. The latter was achieved through means of asking respondents a total of four yes-no questions, each followed by four open-ended questions. The results pertaining to the yes-no questions are first shown in Table 5 and interpreted thereafter, followed by the findings made in relation to the open-ended questions posed:

Table 5. The views of respondents on the PEAS and the PEAST

\begin{tabular}{|l|c|c|c|}
\hline \multicolumn{1}{|c|}{ Question } & Yes & No & TOTAL \\
\hline $\begin{array}{l}\text { Are you satisfied with the PEAS and/or } \\
\text { the PEAST? }\end{array}$ & $31.25 \%$ & $68.75 \%$ & $100 \%$ \\
\hline $\begin{array}{l}\text { Did you receive training on the PEAS } \\
\text { and/or the PEAST? }\end{array}$ & $40.63 \%$ & $59.38 \%$ & $100 \%$ \\
\hline $\begin{array}{l}\text { Have the PEAS and/or the PEAST } \\
\text { helped to improve previous } \\
\text { organizational shortcomings? }\end{array}$ & $68.75 \%$ & $31.25 \%$ & $100 \%$ \\
\hline $\begin{array}{l}\text { Are the PEAS and/or the PEAST easy } \\
\text { to use? }\end{array}$ & $68.75 \%$ & $31.25 \%$ & $100 \%$ \\
\hline
\end{tabular}

Stemming from the results above, it appears that despite the positive evaluation of the PEAS and/or the PEAST (see section 3.2), 68.75\% of respondents were not satisfied with the use of these systems. In order to make more sense of the response of respondents, they were asked the following open-ended question: "Why do you say so?" The following was mentioned:

- "There are still problems with the system such as not being able to log on to the system, or the system just freezes. There are only short periods of time when the system is fast" (Employee A).

- "The system has a slow response time, it is not always up to date, and there are a multitude of errors which pop up frequently such as date incorrectly captured even it is correctly captured " (Employee B).

- "No. The system is still not completely paperless, as it is still dependent on proof of paper documents" (Employee C).

When respondents were asked about whether they have received training on the PEAS and/or the PEAST, 59.38\% indicated that they have not received training to date. This statistic is quite disconcerting, since $68.75 \%$ of respondents have worked at the Master's Office for four years or longer. Notwithstanding the aforesaid, those respondents who received training were asked the following open-ended question: "How effective was the training that you received?" Only one comment was received:

- "Although proper training was given, training constituted only a brief explanation of the system" (Employee C).

When taking into account that training was merely a brief explanation of how the PEAS and/or the PEAST works, it is highly likely that informal training takes place among staff members at the Masters' Office - peer learning. This is particularly supported by the statistic that $68.75 \%$ of respondents regarded the PEAS and/or the PEAST as easy to use. Notwithstanding the aforementioned, although most respondents were not satisfied with the PEAS and/or the PEAST, due to technical issues mostly, $68.75 \%$ of respondents indicated that these systems improved previous shortcomings in the Master's Office. In order to place the latter statistic in better perspective, respondents were asked to motivate their answer (as open-ended question). The following responses were received:

- "...clients can check the information on the website, they do not have to query at our offices" (Employee D).

- "...now the documents can easily be retrieved online by clients and employees ..." (Employee E).

- "We no longer have to look for files. Once the information is on the system, it is easily accessible" (Employee F).

Taking into account the above, the inference made previously that peer-education takes place in the Masters' Office surrounding (informal) training on the PEAS and/or the PEAST is justified. This may be a probable reason why management does not see the need for additional training on the PEAS and/or the PEAST, especially since these systems are regarded as easy to use.

Albeit the above, inferential statistics were performed in order to ascertain whether there existed statistically significant relationships between the productivity and of employees and the 1) training received on the PEAS and/or the PEAST, and 2) easiness of working the PEAS and/or the PEAST. In order to determine the aforementioned, a regression analysis was performed. A summary of the results are shown in Table 6.

Although $\mathrm{R}^{2}$ shows that there existed a "moderate" association between variables influencing "improved productivity" $\left(\mathrm{R}^{2}=0.42\right)$, stemming from the results, there existed only one direct significant positive relationship, namely that between staff members' productivity and the training they received on the PEAS and/or the PEAST $(\beta=0.43)$. As a result, a statistically significant prediction can be made that if staff members receive training (be it formal or informal) on the PEAS and/or the PEAST, they would be more productive in terms of fulfilling their respective job descriptions $(\mathrm{p}=0.001)$. 
Table 6. Summary of regression analysis

\begin{tabular}{|l|c|c|}
\hline \multicolumn{2}{|c|}{ Dependent variable } & $\begin{array}{c}\text { IMPROVED } \\
\text { PRODUCTIVITY }\end{array}$ \\
\hline \multirow{3}{*}{ Independent variables } & $\mathrm{R}^{2}$ & 0.42 \\
\cline { 2 - 3 } & $\mathrm{F}$ & 10.45 \\
\cline { 2 - 3 } & Sig. & $0.000^{* * *}$ \\
\hline \multirow{2}{*}{ TRAINING RECEIVED } & $\beta$ & 0.43 \\
\cline { 2 - 3 } & Sig. & $0.010^{*}$ \\
\hline \multirow{2}{*}{ EASINESS TO WORK } & $\beta$ & 0.34 \\
\cline { 2 - 3 } & Sig. & 0.038 \\
\hline
\end{tabular}

From this observation, clear tangent planes emerge that even if the PEAS and/or the PEAST were easy to use, staff members may still have difficulty in navigating through the PEAS and/or the PEAST (learning on the job) without receiving training on it, be it formal or informal. When staff members did not receive any training on the PEAS and/or the PEAST, it had an adverse influence on their overall productivity.

Lastly, respondents were asked the open-ended question: "In your opinion, what should be done to improve the PEAS and/or the PEAST?" The following was mentioned:

- "We need an in-house IT person, as we log many queries with Helpdesk, but their response time is slow" (Employee G).

- "...faster response time is needed. Downtime of the system is also a huge problem. Furthermore, there should be an "autosave" option built in, as data are often lost during the capturing thereof. This happens frequently when the system freezes or shuts down" (Employee $\mathrm{H})$.

- "Bigger servers are needed to accommodate for the amount of employees that are using the system" (Employee I).

- "The IT team should meet with us regularly in order to discuss system shortcoming and actively implement our suggestions" (Employee F).

These responses shed light on the technical issues which were raised before, which is the predominant reason for staff members' dissatisfaction with the PEAS and/or the PEAST.

\section{Recommendations}

To better meet its current and future needs, the Master's Office can consider implementing some of the recommendations made by the employees in order to enhance the performance of the systems. Larger servers are required in order to accommodate the large amount of employees using the systems and to address the speed of the systems identified by the employees. The need of an in-house IT person was also identified by the users. This would aid in ensuring that issues such as slowness and errors around the system can be immediately addressed. Lastly discussions should take place between the IT team and employees to discuss the systems shortcomings in order to further improve the systems. This is especially the case where staff members received training on the PEAS and/or the PEAST; though they are more productive after receiving training (based on the regression analysis), they need support from the IT team when required (be on standby).

\section{Conclusion}

From the findings made and recommendations, it is evident that the PEAS and the PEAST added value to respondents, as it allowed them to respond to customer enquiries quicker and also perform basic administration such as search and faster retrieval of information. Improvements made to the previous organizational shortcomings have similarly added value to the Master's Office.

However, the employees are dissatisfied with the inconsistencies of the systems. System slowness and errors were identified as some of the reasons why the employees were dissatisfied with the system.

It is worth noting that although employees are dissatisfied with the system, it was found that the system is easy to use. This has led to the initial conclusion that the lack of training was due to the easy nature of the system. Upon further testing, it was found that even if staff members did not receive formal training, which constituted mostly a brief explanation of how the PEAS and/or the PEAST works, they made use of peer-learning to receive informal training from one another. This is particularly true, since there existed a statistically significant positive relationship between the training received by staff members (be it formal or informal) and their overall productivity.

Future operations at the Master's Office can be built upon the value currently added by the systems and also by utilizing some of the recommendations made by the employees on how to further improve the systems.

\section{References}

1. Abbot, B. (2001). The state of electronic records management in South Africa: an overview, ESARBICA Journal, 20, pp. 62-70.

2. Beaumont, P.B. and. Vogel, J.C. (1989). Patterns in the Age and Context Of Rock Art In The Northern Cape, South African Archaeological Bulletin, 44, pp. 73-81. 
3. Bechtold, J., Kaspereit, T., Kirsch, N., Lyakina, Y., Seib, S., Spiekermann, S. \& Stengert, K. (2013). Corporate sustainability in the estimation of financial distress likelihood - Evidence from the world stock markets during the financial crisis, Research Journal of Finance and Accounting, 4(5), pp. 205-211.

4. Bloomberg. (1975). The office of the future. Available from: http://www.bloomberg.com/bw/stories/1975 06-30/the-office-of-the-futurebusinessweek-business-news-stock-market-and-financial-advice [Accessed on 26/08/2015].

5. Bradwell, R.S. (2005). The economics of going paperless: the case of container freight company, Master Degree thesis, Kansas State University, Manhattan Kansas.

6. Brooks, C. (2014). 10 Reasons to Take Your Business Paperless. Available from: http://www.businessnewsdaily.com/6461-reasons-to-go-paperless.html.

7. Calitz, J. and Boraine, A. (2005). The role of the master of the high court as regulator in a changing liquidation environment: a South African perspective, Tydskrif vir die Suid-Afrikaanse Reg, 4, pp. 728-744.

8. Collis, J. and Hussey, R. (2009). Business Research: A Practical Guide for Undergraduate and Post Graduate Students. Basingstoke: Palgrave Macmillan.

9. Consumer Reports. (2013). The High Cost of Wasted Printer Ink. Available from: http://www.consumerreports.org/cro/magazine/2013/08/the-high-cost-of-wasted-printer-ink/index.htm.

10. Cowan, R. (1976). The "Industrial Revolution" in the Home: Household Technology and Social Change in the 20th century, Technology and Culture, 17(1), pp. 1-23.

11. De Villiers W Die. (1923). Ou-Hollandse insolvensiereg en die eerste vaste insolvensiereg van die Kaap de Goede Hoop. Unpublished LLD Thesis, University of Groningen, Leiden.

12. Department of Justice and Constitutional Development. (2016a). Masters Office Staff Telephone ListJanuary 2016.xlsx. Available from: http://www.justice.gov.za/master/contacts/moh-capetown.pdf.

13. Department of Justice and Constitutional Development. (2016b). About the Master of the High Court. Available from: http://www.justice.gov.za/master/about.htm.

14. Department of Justice and Constitutional Development. (2016c). Deceased Estates. Available from: http://www.justice.gov.za/master/deceased.html.

15. Department of Justice and Constitutional Development. (2016d). Administration of Trusts. Available from: http://www.justice.gov.za/master/trust.html.

16. Directorate State Archives and Heraldic Services. (1999). Annual reports. Pretoria: Department of Arts, Culture, Science and Technology.

17. Gerber, J. (1987). The South African Government Archive Service: Past, Present and Future. University of College: London.

18. Germain, C. (2007). Legal Information Management in a Global and Digital Age: Revolution and Tradition, International Journal of Legal Information, 35(1), pp. 134-163.

19. Gladwell, M. (2002). The Social life of paper. Available from: http://www.newyorker.com/magazine/2002/03/25/the-social-life-of-paper.

20. Gokhale, A. and Sharma, D. (2014). Green computing: An eco-friendly approach toward computing, Journal of Indian Research, 2(2), pp. 152-157.

21. Greenwood, J. (1999). The third Industrial Revolution: Technology, productivity, and income inequality, Economic Review, 35(1), pp. 2-12.

22. Gupta, S. (2015). Paperless Society - From Vision to Fulfillment, Global Journal of Enterprise Information System, 7(1), pp. 45-53.

23. Harris, V. (1997). Exploring archives: an introduction to archival ideas and practice in South Africa. Pretoria: NASA.

24. Harris, V. (2000). Exploring archives: an introduction to archival ideas and practice in South Africa. 2nd edition. Pretoria: NASA.

25. Harris, V. (2002). The Archival Sliver: Power, Memory, and Archives in South Africa, Archival Science, 2(1), pp. 63-86.

26. Hill, J. (2015). The Paperless Movement. Mini-dissertation submitted for the partial fulfillment of a Honours Degree in Business Administration. Available from: http://www.hs.unp.ac.za/infs/thesispn.pdf\#search='patrick\%20ngulube'.

27. Johnston, G.P. and Bowen, D.V. (2005). The benefits of electronic records management systems: a general review of published and some unpublished cases, Records Management Journal, 15(3), pp. 131-140.

28. Jurkiewicz, C. (2000). Generation X and the Public Employee, Public Personnel Management, 29(1), pp. $55-74$.

29. Kirkwood, C. and Venter, L. (1999). Strategies for the management and appraisal of electronic records in the public sector, SA Archives Journal, 41(1), pp. 29-40.

30. Kwatsha, N. (2010). Factors affecting the implementation of an electronic document and records management system. Unpublished Master Thesis, University of Stellenbosch.

31. Law Society of South Africa. (2015). ICMS MASTERS - Inter Vivos Trusts Peast - Paperless Estate Administration System - Trusts. Available from http://www.lssa.org.za/upload/ICMS\%20PEAST.pdf.

32. Leedy, P. and Ormrod, J. (2010). Practical Research - Planning and Design. New York: Pearson. 
33. Liu, Z. (2008). Paper to Digital: Documents in the Information Age. London: Libraries Unlimited.

34. Macrae, D. (1951). Cybernetics and Social Science, The British Journal of Sociology, 2(1), pp. 135-149.

35. McAllister, B. (2005). Whatever happened to yesterday's hot technologies?. Available from: http://www.infoworld.com/article/2670726/application-development/whatever-happened-to-yesterday-s-hottechnologies-.html.

36. Meyer, P. (2009). The Vanishing Newspaper: Saving Journalism in the Information Age. University of Missouri Press: Columbia.

37. Mokyr, J. (1997). Are We Living in the Middle of an Industrial Revolution? Economic Review - Federal Reserve Bank of Kansas City, 82(1), pp. 31-44.

38. Moloi, J. (2001). E-records readiness in the public sector in Botswana, ESARBICA Journal, 28(1), pp. 122-124.

39. Mphidi, H. and Snyman, R. (2004). The utilisation of an intranet as a knowledge management tool in academic libraries, The Electronic Library, 22(5), pp. 393-400.

40. Muchaonyerwa, N. and Khayundi, F. (2014). The Management of Digital Records in the Office of the Premier of the Eastern Cape Province, South Africa, African Journal Of Library, Archives and Information Science, 24(1), pp. 41-52.

41. Mukwevho, J. and Jacobs, L. (2012). The importance of the quality of electronic records Management in Enhancing Accountability in the South African Public Service: A Case Study of a National Department, Mousaion, 30(2), pp. 33-51.

42. National Archives and Records Service of South Africa. (2006). Managing electronic records in governmental bodies: policy, principles and requirements. 2nd edition. Pretoria. Department of Arts and Culture.

43. Ngoaketsi, J. (2003). Embracing opportunity and managing challenges of using technology in records management: a review of National Archives and Records Service of South Africa policy on the management of electronic records in governmental bodies, Archives News, 45(4), pp. 21-33.

44. Ngoepe, M. (2008a). Strategies for preservation of electronic records in South Africa: implications on access to information. Paper read at Poussière d'étoiles' 2nd annual knowledge, archives and records management (KARM) conference in Polokwane, SA, 6 - 7 May 2008.

45. Ngoepe, M. (2008b). An Exploration of Records Management Trends in the South African Public Sector: A case study of the Department of Provincial and Local Government. Unpublished Masters Dissertation, University of South Africa (UNISA).

46. Ngoepe, M. (2014). The role of records management as a tool to identify risks in the public sector in South Africa, South African Journal of Information Management, 16(1), pp. 1-8.

47. Ngoepe, M. and Keakopa, S.M. (2011). An assessment of the state of national archival and records systems in the ESARBICA region, Records Management Journal, 21 (2), pp. 145-160.

48. Ngoepe, M. and van der Walt, T. (2009). A Framework for a Records Management Program: Lessons from the Department of Cooperative Governance and Traditional Affairs in South Africa, Mousaion, 28 (2), pp. 82-106.

49. Ngulube, P. (2002). Challenges to preservation of our archival heritage, South African Archives Journal, 42(1), pp. 27-36.

50. Ngulube, P. (2003). Preservation and access to public records and archives in South Africa. PHD Thesis. Pietermaritzburg: University of Natal.

51. Ngulube, P. (2006). Nature and accessibility of public archives in custody of selected archival institutions in Africa, ESARBICA Journal, 25, pp. 106-124.

52. Orantes-Jiménez, S., Zavala-Galindo, A. and Vázquez-Álvarez, G. (2015). Paperless Office: A new proposal for organizations, Systemics, Cybernetics and Informatics, 13(3), pp. 47-55.

53. Remenyi, D., Williams, B., Money, A. and Swartz, E. (2009). Doing research in business and management: an introduction to process and method. London, Sage.

54. Sanders, T. (2009). How HR Can Green Up Your Company, Employment Relations Today, 35(4), pp. 17-23.

55. Sellen, A. and Harper, R. (2002). The Myth of the Paperless Office. London: MIT Press.

56. South Africa. (2013). The Department of Justice and Constitutional Development Annual Report 2013-2014. Pretoria.

57. State of the Archives. (2014). Analysis of South Africa's national archives system, 2014. Available from: http://pmg-assets.s3-website-eu-west-1.amazonaws.com/150901archives.pdf.

58. Statistics South Africa. (2010). South African Statistical Quality Assessment Framework (SASQAF): Operational Standards and Guidelines. Pretoria.

59. TANAP. (2015). Western Cape Archives and Records Service. Available from: http://www.tanap.net/content/archives/archives.cfm?ArticleID=203.

60. The Presidency, Department of Performance Monitoring and Evaluation. (2009). Improving government performance: our approach. Pretoria: The Presidency.

61. Van Meel, J. (2011). The origins of new ways of working, Facilities, 29 (9), pp. 357-367.

62. Verster, F. (2007). 72 Roeland Street: the home of our history, Village life, 22, pp. 18-21. 
63. Weeks, R.V. (2014). The implementation of an electronic patient healthcare record system: a South African case study, Journal of Contemporary Management, 11(1), pp. 101-119.

64. Wilkinson, A., Hill, M. and Gollan, P. (2001). The sustainability debate, International Journal of Operations and Production Management, 21(12), pp. 1492-1502.

65. Williams, R., Larson, E. and Ross, M. (1987). Materials, affluence, and industrial energy use, Annual Review of Energy and Environment, 12(1), pp. 99-144.

66. Yang, L., Rida, A., Vyas, R. and Tentzeris, M. (2007). RFID Tag and RF Structures on a Paper Substrate Using Inkjet-Printing Technology, IEEE Transactions on Microwave Theory and Techniques, 55(12), pp. 2894-2901.

67. Yuba, M. (2013). The role of the National Archives and Records Service of South Africa in the young democracy. Unpublished Dissertation, University of the Witwatersrand. 